\title{
Pengaruh Ekstrak Air Daun Kelor Terhadap Kadar Leptin dan Malondialdehyde Lemak Visceral Tikus Wistar yang Dipapar Depo Medroxyprogesterone Acetate
}

\author{
Nur Aini R. Hastuti ${ }^{*}$, Sri Winarsih², Pande Made Dwijayasa ${ }^{3}$ \\ ${ }^{1}$ Program Studi S1 Kebidanan Fakultas Kedokteran Universitas Brawijaya Malang \\ ${ }^{2}$ Departemen Mikrobiologi Fakultas Kedokteran Universitas Brawijaya Malang \\ ${ }^{3}$ Divisi Obstetri Ginekologi Fakultas Kedokteran Universitas Brawijaya Malang / RS dr. Saiful Anwar \\ Email* : nurehas@gmail.com \\ HP : 085642140459
}

\begin{abstract}
Depo medroxyprogesterone user is associated with increased adipogenesis and oxidative stress. Moringa oleifera is a natur pholiphenols antioxidant. This aim of this study is to prove water extract of Moringa leaf affect leptin and malondialdehyde (MDA) levels of the visceral fat wistar rats exposed DMPA. 25 female wistar rats devide into negative controls $((0,2 \mathrm{ml}$ aquades i.m and $1 \mathrm{cc}$ aquades/oral), positive controls (DMPA 2,7mg i.m and $1 \mathrm{cc}$ aquades/oral), DMPA 2,7 $\mathrm{mg}$ and water extract of Moringa oleifera $100 \mathrm{mg} / \mathrm{kgBW}, 150 \mathrm{mg} / \mathrm{kgBW}, 200 \mathrm{mg} / \mathrm{kgBW}$ respectively with replication of 5 rats each group. The study was perform in four weeks and followed with removal of visceral fat tissue. Result: leptin levels were measured by Elisa and MDA levels using TBARS methode using spectrophotometer. Rats treated by DMPA (positive control) had the highest mean leptin and MDA levels compared to not exposed group DMPA (negative control) or rats that received water extract of Moringa leaves (the treatment group). ANOVA test obtained $p=0,027$ (leptin) and $p=0,001$ (MDA) so that can be interpreted that there are significant difference for leptin and MDA levels after received water extract of Moringa oleifera leaves in various doses. Pearson Product Moment test results $p=0.010$ (leptin) and $p=0.000$ (MDA). The result of this study water extract of Moringa oleifera reduce leptin and MDA levels of wistar rat exposed Depo Medroxyprogesterone Acetate.
\end{abstract}

Keywords : Adipose, Malondialdehyde, Leptin, Visceral Lipid, Moringe Leaf

\section{ABSTRAK}

Penggunaan Depo Medroxyprogesterone dikaitkan dengan peningkatan adipogenesis dan oksidatif stress. Daun kelor (Moringa oleifera) adalah antioksidan alami dengan kandungan polifenol. Penelitian ini bertujuan untuk membuktikan ekstrak air daun kelor mempengaruhi kadar leptin dan malondialdehyde (MDA) lemak visceral tikus wistar yang dipapar Depo 
Medroxyprogesterone Acetate (DMPA). 25 tikus Wistar betina yang dibagi dalam kelompok kontrol negatif $(0,2 \mathrm{ml}$ aquades i.m dan $1 \mathrm{cc}$ aquades/oral), kontrol positif (DMPA 2,7mg i.m dan 1 ccaquades/oral), perlakuan DMPA 2,7 mg dengan ekstrak air daun kelor $100 \mathrm{mg} / \mathrm{kgBB}, 150$ $\mathrm{mg} / \mathrm{kgBB}$, dan $200 \mathrm{mg} / \mathrm{kgBB}$. Penelitian dilakukan selama empat minggu dan dilakukan pengambilan jaringan lemak visceral. Kadar leptin diukur dengan metode ELISA dan kadar MDA dilakukan dengan metode TBARs menggunakan spektrofotometer. Tikus yang dipapar DMPA (kontrol positif) memiliki rerata kadar leptin dan MDA yang tertinggi dibanding dengan kelompok tikus yang tidak dipapar DMPA (kontrol negatif) ataupun tikus yang mendapat ekstrak air daun kelor (kelompok perlakuan). Uji ANOVA diperoleh $p=0,027$ (leptin) dan $p=0,001$ (MDA) sehingga dapat diintepretasikan terdapat perbedaan yang signifikan pada kadar leptin dan MDA setelah pemberian ekstrak air daun kelor dalam berbagai dosis. Ekstrak air daun kelor menurunkan kadar leptin dan DMPA. Hasil uji Pearson Product Moment $p=0,010$ (leptin) dan $p=0.000$ (MDA). Hasil dari penelitian ini menyimpulkan ekstrak air daun kelor mampu menurunkan kadar leptin dan MDA lemak visceral tikus wistar yang dipapar Depo Medroxyprogesterone Acetate.

Kata kunci: Adiposa, Malondialdehyde, Leptin, Lemak visceral, Daun kelor

1Korespondensi: Nur Aini Retno Hastuti. Surel: nurehas@gmail.com 


\section{PENDAHULUAN}

Kontrasepsi suntik adalah metode kontrasepsi yang menempati pilihan pertama. Depo medroxyprogesterone acetate (DMPA) adalah kontrasepsi suntik yang diberikan setiap 3 bulan dengan mekanisme mencegah terjadinya ovulasi. Masalah utama pada pengguna DMPA antara lain: perdarahan menstruasi yang tidak teratur, kenaikan berat badan, dan nyeri payudara ${ }^{1}$. Peningkatan berat badan sebagai efek penggunaan DMPA merupakan efek yang paling tidak disukai wanita. Selama tahun pertama penggunaan DMPA menyebabkan kenaikan berat badan $\pm 3 \mathrm{~kg}$ dan dalam 30 bulan terjadi kenaikan $\pm 6,1 \mathrm{~kg}^{2}$. Keadaan hipoestrogen pada akseptor DMPA dikaitkan dengan peningkatan adipogenesis yang menyebabkan terjadinya kenaikan berat badan yang sejalan dengan akumulasi lemak visceral yang memproduksi leptin dan memiliki peran penting dalam signaling jaringan adiposa ${ }^{3}$. Hormon leptin dihasilkan oleh jaringan adiposa anggota adipositokinin yang berperan dalam signaling hormon jaringan adiposa. Leptin adalah hormon yang mengatur nafsu makan dan peningkatan berat badan ${ }^{4}$. Hipoestrogen pada akseptor DMPA meningkatkan stress oksidatif ${ }^{3}$. Estrogen selain sebagai hormon seks juga berperan sebagai antioksidan dalam tubuh. Kadar antioksidan yang rendah dalam tubuh dapat meningkatkan terjadinya stress oksidatif dengan penanda tingginya kadar MDA ${ }^{5,6}$.

$$
\text { Kelor (Moringa oleifera) }
$$
merupakan keluarga Moringaceae yang kaya akan berbagai fitokimia penting ${ }^{7}$ Kelor merupakan antioksidan yang mengandung polifenol. Masyarakat telah banyak mengkonsumsi daun kelor yang telah diketahui banyak manfaatnya. Kelor yang mudah didapatkan dan harga murah menjadi alasan lain bagi masyarakat untuk mengkonsumsi daun kelor. Ekstrak air daun kelor memiliki kemiripan dalam pemanfaatan daun kelor dalam masyarakat melalui proses perendaman dalam air panas. Belum ada penelitian mengevaluasi efek pemberian ekstrak air daun kelor terhadap kadar leptin dan MDA pada tikus yang dipapar DMPA.

\section{METODE PENELITIAN Hewan coba}

25 tikus wistar betina terbagi menjadi 5 kelompok; kontrol negatif $(0,2 \mathrm{ml}$ aquades i.m dan $1 \mathrm{cc}$ aquades/oral), kontrol positif (DMPA $2,7 \mathrm{mg}$ i.m dan $1 \mathrm{cc}$ aquades/oral), perlakuan DMPA 2,7 mg dengan ekstrak air daun kelor $100 \mathrm{mg} / \mathrm{kgBB}$, $150 \mathrm{mg} / \mathrm{kgBB}$, dan $200 \mathrm{mg} / \mathrm{kgBB}$. Tikus berasal dari Dinas Pertanian Kota Malang berusia 9-12 minggu dan berat badan 100-250 g. Tikus ditempatkan pada kandang dengan alas sekam, suhu $20-28^{\circ} \mathrm{C}$, dan pengaturan cahaya 12 jam terang. Tikus mendapat makan dan minum sesuai kebutuhan. 


\section{Paparan DMPA}

DMPA diinjeksikan

2,7mg/tikus/minggu selama 4 minggu. DMPA diencerkan dengan aquades dan diberikan secara intra muscular ${ }^{8,9}$.

\section{Ekstrak air daun kelor}

Simplisia daun kelor diperoleh dari Balai Tanaman Obat Materia Medika Batu Indonesia. $100 \mathrm{~g}$ simplisia daun kelor ditambahkan pada 1 liter air panas suhu $70^{\circ} \mathrm{C}$. Setelah tercampur selanjutnya mendiamkannya selama 1 jam dan menyaringnya untuk mendapat ekstrak air daun kelor. Ekstrak air daun kelor yang telah diperoleh dilakukan freeze dry untuk mendapatkan ekstrak padat yang diinginkan ${ }^{10}$.

\section{Uji kadar leptin}

Uji kadar leptin menggunakan Rat LEP (Leptin) ELISA Kit (No. Katalog: E-EL-R0582) dari Elabscience Biotecnology. Uji dilakukan sesuai dengan prosedur pada kit.

\section{Uji kadar MDA}

NWLSS ${ }^{\mathrm{TM}}$ Malondialdehyde Assay (No. Produk NWK-MDA01) dari Northwest Life Science Specialities. Uji dilakukan dengan metode TBARs sesuai pedoman pada kit.

\section{Analisis statistik}

Data disajikan dengan rerata \pm SE. Uji beda menggunakan One Way Anova dengan post hoc LSD. Uji korelasi menggunakan Pearson Product Moment. Dikatakan signifikan jika $p<0,05$. Analisis statistik menggunakan SPSS 21.0

\section{HASIL PENELITIAN}

1 liter ekstrak air daun kelor menghasilkan 67,53 gram bentuk padat dengan metode freeze drying. Hasil frezze drying ekstrak air daun kelor disimpan pada suhu $4^{\circ} \mathrm{C}$ sebelum digunakan. Ekstrak air daun kelor mengandung total fenol sebesar $1,38 \%$ dan total flavonoid sebesar $0,063 \%$.

Rerata kadar leptin dan MDA tikus wistar yang dipapar DMPA dan pemberian ekstrak air daun kelor dipaparkan pada tabel 1, gambar 1 , dan gambar 2 .

Tabel 1. Rerata kadar leptin dan MDA pada tikus wistar

\begin{tabular}{cccc}
\hline Kel & $\begin{array}{c}\text { Jumlah } \\
\text { Sampel }\end{array}$ & $\begin{array}{c}\text { Kadar Leptin } \\
(\text { Rerata } \pm \text { SE) } \\
(\mathbf{n g} / \mathbf{m l})\end{array}$ & $\begin{array}{c}\text { Kadar MDA } \\
(\text { Rerata } \mathbf{S E}) \\
(\boldsymbol{\mu M})\end{array}$ \\
\hline KN & 5 & $7,5 \pm 1,36$ & $1,37 \pm 0,15$ \\
\hline KP & 5 & $12,35 \pm 0,89$ & $1,61 \pm 0,22$ \\
\hline P1 & 5 & $10,81 \pm 0,84$ & $1,35 \pm 0,12$ \\
\hline P2 & 5 & $10,33 \pm 0,59$ & $0,90 \pm 0,08$ \\
\hline P3 & 5 & $8,95 \pm 1,11$ & $0,76 \pm 0,03$ \\
\hline
\end{tabular}

Pada KP terjadi kenaikan kadar leptin, hal ini menunjukkan bahwa paparan DMPA meningkatkan kadar leptin. Terdapat perbedaan yang siginifikan pada kadar leptin setelah pemberian ekstrak air daun kelor dalam berbagai dosis $(p=0,027)$. Kadar leptin selanjutnya menurun pada kelompok perlakuan dikarenakan paparan ekstrak air daun kelor. Ada perbedaan yang signifikan pada $\mathrm{KN}$ terhadap $\mathrm{KP}(p=$ $0,003)$ dan P1 $(p=0,029)$. 

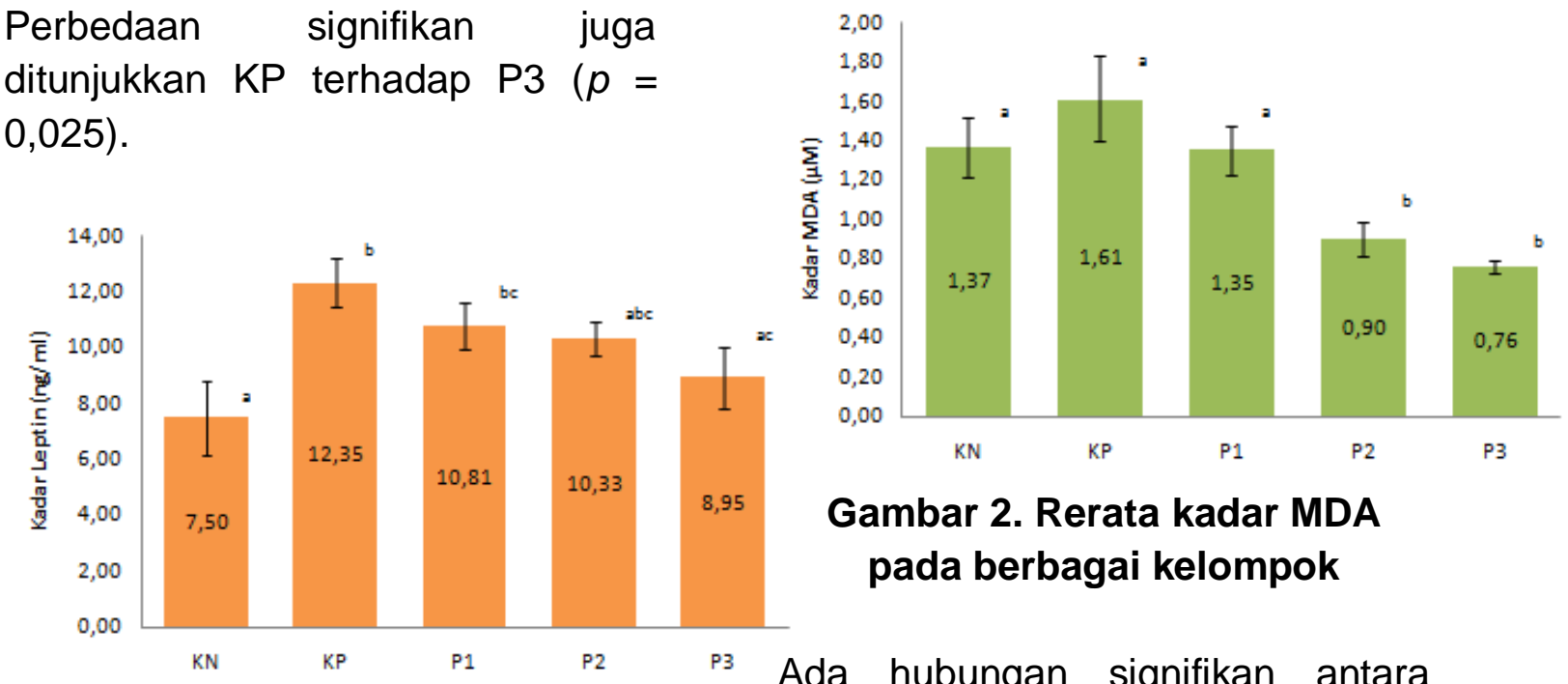

\section{Gambar 2. Rerata kadar MDA pada berbagai kelompok}

\section{Gambar 1. Rerata kadar leptin pada berbagai kelompok}

Terdapat hubungan signifikan pemberian berbagai dosis ekstrak air daun kelor tehadap kadar leptin pada tikus wistar $(p=0,010)$. $R=-$ 0,559 menunjukkan korelasi yang sedang dengan arah hubungan negatif (semakin tinggi dosis semakin rendah kadar leptin).

Kadar MDA meningkat pada $\mathrm{KP}$ dan menurun pada $\mathrm{P} 1, \mathrm{P} 2$, dan P3. Ada perbedaan yang signifikan pada kadar MDA setelah pemberian ekstrak air daun kelor dalam berbagai dosis $(p=0,001)$. Perbedaan signifikan ditunjukkan pada kelompok KN dengan P2 ( $p=$ 0.017) dan P3 ( $p=0.002)$. Perbedaan signifikan ditunjukkan pula pada KP terhadap P2 ( $p=$ $0.001)$ dan P3 $(p=0.000)$. Serta ada perbedaan yang bermakna pada $\mathrm{P} 1$ dibandingkan P2 $(p=$ $0.020)$ dan perlakuan $3(p=0.030)$.
Ada hubungan signifikan antara pemberian berbagai dosis ekstrak air daun kelor tehadap kadar leptin pada tikus wistar. $R=-0,776$ menunjukkan korelasi kuat dengan arah hubungan negatif (semakin tinggi dosis semakin rendah kadar MDA).

\section{PEMBAHASAN}

Pemaparan menyebabkan DMPA dapat kondisi hipoestrogen 3,11 . Estrogen berpengaruh pada regulasi dan metabolisme lemak $^{12}$. Penurunan kadar estrogen akan berpengaruh pada jumlah lemak tubuh. Estrogen juga meningkatkan, memelihara, mengontrol distribusi lemak tubuh dan metabolisme jaringan lemak $^{13,14}$. Leptin adalah pengatur penting massa jaringan adiposa dan berat badan. Leptin bekerja dengan menghambat asupan makanan dan merangsang pengeluaran energi ${ }^{15}$. Keadaan hipoestrogen yang diakibatkan oleh paparan DMPA berkorelasi dengan peningkatan adipogenesis. Pada individu dengan simpanan lemak berlebih tubuh 
memproduksi leptin sebanding dengan tingginya simpanan lemak dalam tubuh. Quercetin dalam ekstrak air daun kelor menghambat adipogenesis seperti yang terlihat oleh penghambatan akumulasi lipid dan faktor adipogenik pada MRNA dan pada tingkat protein ${ }^{16}$. Hal ini sesuai dengan penelitian sebelumnya yang membuktikan daun kelor menurunkan ekspresi leptin mRNA yang sejajar dengan penurunan berat badan tikus betina ${ }^{17}$. Efek antiobesitas daun kelor juga dapat menurunkan berat badan, kolesterol total, trigliserid dan LDL tanpa mengurangi asupan pakan pada tikus yang mendapat diet tinggi lemak dan ekstrak daun kelor ${ }^{18,19}$. Pemberian ekstrak daun kelor dan simvastatin $4 \mathrm{mg} / \mathrm{kg} /$ oral dapat menurunkan kolesterol serum, trgliserida, VLDL, LDL, indeks aterogenik dan peningkatan HDL dibandingkan kelompok kontrol secara signifikan pada kelompok simvastatin, kelompok Moringa oleifera 300 mg/kg dan 600 mg/kg 20 .

Penggunaan kontrasepsi DMPA dapat meningkatkan stress oksidatif, dan menurunkan kemampuan antioksidan endogen, yang salah satu indikatornnya adalah peningkatan kadar $\mathrm{MDA}^{3,11}$. Pada pengguna DMPA jangka panjang terjadi penurunan level estrogen yang menyebabkan terjadinya hipoestrogen ${ }^{21}$. Estrogen berfungsi sebagai hormon seks dan juga berfungsi sebagai antioksidan ${ }^{22}$. Estrogen berperan dalam melindungi lipoprotein dari oksidasi.
Ketidakseimbangan jumlah antioksidan dan ROS dalam tubuh menyebabkan stress oksidatif. Tingginya kadar radikal bebas dalam tubuh dapat ditunjukkan dengan tingginya kadar malondialdehyde (MDA) yang merupakan produk peroksida lipid ${ }^{3}$. Daun kelor merupakan antioksidan yang mampu mereduksi stress oksidatif dalam tubuh. Ekstrak air daun kelor meunjukkan efek kuat pada radikal bebas. Kandungan polifenol dalam daun kelor dapat menurunkan kadar MDA $^{23}$. Ekstrak daun Moringa oleifera menunjukkan kandungan polifenol yang tinggi (50 $\mathrm{mg}$ polifenol/g daun kering) ${ }^{24}$. Kandungan total fenol ekstrak air daun kelor bubuk adalah $10 \mathrm{mg} / \mathrm{ml}$ yang setara dengan $205.8 \pm 0.22$ $\mu \mathrm{g} / \mathrm{ml}$ asam gallic. Daun kelor memiliki perlindungan terhadap kerusakan DNA dan sel dari stress oksidatif. Ekstrak daun kelor menghambat peroksida lipid sekitar $30 \%$ pada konsentrasi $30 \mu \mathrm{g} / \mathrm{ml}^{25}$. Hasil penelitian terkait efek antioksidan ekstrak daun kelor yang menurunkan kadar MDA mendukung penelitian sebelumnya ${ }^{26-31}$.

Penelitian pada tkus menunjukkan ekstrak air daun kelor relatif lebih aman pada pemberian oral (sampai 1500 mg/kg). Namun, diperlukan kehati-hatian dalam pemberian jangka panjang. Diperlukan penelitian lebih lanjut mengenai efek mutagenik, teratogenik dan karsinogenik ${ }^{32}$. Penelitian tambahan pada manusia 
dengan menggukanan dosis ekstrak yang standar sangat diperlukan. Standarisasi produk merupakan masalah yang dihadapi ${ }^{33}$.

\section{SIMPULAN}

Ekstrak air daun kelor mampu menurunkan kadar leptin dan MDA lemak visceral tikus wistar yang dipapar Depo Medroxyprogesterone Acetate

\section{Conflict of interest}

Peneliti menyatakan tidak ada nya konflik kepentingan

\section{Daftar Pustaka}

1. Speroff L, Fritz MA. Clinical gynecologic endocrinology and infertility: lippincott Williams \& wilkins; 2005.

2. Dal'Ava N, Bahamondes L, Bahamondes MV, Bottura BF, Monteiro I. Body weight and body composition of depot medroxyprogesterone acetate users. Contraception. 2014;90(2):182-7.

3. Faddah L, Al-Rehany M, AbdelHamid N, Bakeet A. Oxidative stress, lipid profile and liver functions in average Egyptian long term depo medroxy progesterone acetate (DMPA) users. Molecules. 2005;10(9):1145-52.

4. Limanan D, Prijanti A. Hantaran Sinyal Leptin dan Obesitas: Hubungan dengan Penyakit Kardiovaskuler. FK UI: Tesis; 2013.

5. Liu R, Pulliam DA, Liu Y, Salmon AB. Dynamic differences in oxidative stress and the regulation of metabolism with age in visceral versus subcutaneous adipose. Redox biology. 2015;6:401-8.

6. Prázny $M$, Škrha J, Hilgeřtová J. Plasma malondialdehyde and obesity: is there a relationship? Clinical chemistry and laboratory medicine. 1999;37(11-12):112930.

7. Gopalakrishnan L, Doriya K, Kumar DS. Moringa oleifera: A review on nutritive importance and its medicinal application. Food Science and Human Wellness. 2016;5(2):49-56.

8. Veri N, Aulia F, Ratnawati R, Hidayati DYN, Noorhamdani N, Dwijayasa PM. Protective effect of green tea against ovarian and endometrial apoptoses in rats treated with depot medroxyprogesterone acetate. Biomarkers and Genomic Medicine. 2015;7(3):105-9.

9. Wahyuni ES, Wiyasa IWA, Nurdiana N. Combined high dose vitamin $\mathrm{C}$ and $\mathrm{E}$ increases oxidative stress and visceral fat mass in rats treated by depotmedroxyprogesterone acetate. Middle East Fertility Society Journal. 2016;21(4):259-63.

10. Lamou B, Taiwe GS, Hamadou A, Houlray J, Atour MM, Tan PV. Antioxidant and antifatigue properties of the aqueous extract of Moringa oleifera in rats subjected to forced swimming endurance test. Oxidative medicine and cellular longevity. 2016;2016.

11. Bakry S, Abdullah A. Effect of depot medroxyprogesterone (DMPA) on body weight and serum lipid profile in adult female rats. Egyptian Journal of 
Biochemistry and Molecular Biology. 2009;27(1):17-30.

12. Oosthuyse T, Bosch AN. Oestrogen's regulation of fat metabolism during exercise and gender specific effects. Current opinion in pharmacology. 2012;12(3):363-71.

13. Cooke PS, Heine PA, Taylor JA, Lubahn DB. The role of estrogen and estrogen receptor- $\alpha$ in male adipose tissue. Molecular and cellular endocrinology. 2001;178(1):147-54.

14. Cooke PS, Naaz A. Role of estrogens in adipocyte development and function. Experimental biology and medicine. 2004;229(11):1127-35.

15. Paracchini V, Pedotti P, Taioli E. Genetics of leptin and obesity: a HuGE review. American journal of epidemiology. 2005;162(2):101-14.

16. Swick JC. Effect of the Flavonoid Quercetin on Adipocytes. 2011.

17. Metwally FM, Rashad HM, Ahmed HH, Mahmoud AA, Raouf ERA, Abdalla AM. Molecular mechanisms of the anti-obesity potential effect of Moringa oleifera in the experimental model. Asian Pacific Journal of Tropical Biomedicine. 2017;7(3):214-21.

18. Ghasi S, Nwobodo E, Ofili J. Hypocholesterolemic effects of crude extract of leaf of Moringa oleifera Lam in high-fat diet fed Wistar rats. Journal of Ethnopharmacology. 2000;69(1):21-5.

19. Bais S, Singh GS, Sharma R. Antiobesity and hypolipidemic activity of Moringa oleifera leaves against high fat diet-induced obesity in rats. Advances in Biology. 2014;2014.

20. Jain PG, Patil SD, Haswani NG, Girase MV, Surana SJ. Hypolipidemic activity of Moringa oleifera Lam., Moringaceae, on high fat diet induced hyperlipidemia in albino rats. Revista Brasileira de Farmacognosia. 2010;20(6):96973.

21. Reifsnider E, Mendias N, Davila Y, Bever Babendure J. Contraception and the obese woman. Journal of the American Association of Nurse Practitioners. 2013;25(5):223-33.

22. Andriantsitohaina $R$, Auger $\mathrm{C}$, Chataigneau T, ÉtienneSelloum N, Li H, Martínez MC, et al. Molecular mechanisms of the cardiovascular protective effects of polyphenols. British Journal of Nutrition. 2012;108(09):1532-49.

23. Sukina B, Gwenny I, Suhartati S, Harianto N. Katekin Daun Teh Hijau (Camelia sinensis) Terhadap Malondialdehyde Dan Super Oxide Dismutase. Indonesian Journal of Clinical Pathology and Medical Laboratory. 2016;19(2):92-7.

24. Sikder K, Sinha M, Das N, Das D, Datta S, Dey S. Moringa oleifera Leaf extract prevents in vitro oxidative DNA damage. Asian J Pharm Clin Res. 2013;6:159-63.

25. Chumark $P$, Khunawat $P$, Sanvarinda $Y$, Phornchirasilp $S$, Morales NP, Phivthong-ngam L, et al. The in vitro and ex vivo antioxidant properties, hypolipidaemic and antiatherosclerotic activities of water extract of Moringa oleifera Lam. leaves. Journal of 
ethnopharmacology.

2008;116(3):439-46.

26. Sreelatha $S$, Padma $P$. Antioxidant activity and total phenolic content of Moringa oleifera leaves in two stages of maturity. Plant foods for human nutrition. 2009;64(4):303.

27. Pasha S, Khaleel M, Som S. Effect of Moringa oleifera on stress induced brain lipid peroxidation in rats. Research Journal of Pharmaceutical Biological and Chemical Sciences. 2010;1(3):336-42.

28. Luqman $\mathrm{S}$, Srivastava $\mathrm{S}$, Kumar R, Maurya AK, Chanda D. Experimental assessment of Moringa oleifera leaf and fruit for its antistress, antioxidant, and scavenging potential using in vitro and in vivo assays. EvidenceBased Complementary and Alternative Medicine. 2011;2012.

29. Moyo B, Oyedemi S, Masika P, Muchenje V. Polyphenolic content and antioxidant properties of Moringa oleifera leaf extracts and enzymatic activity of liver from goats supplemented with Moringa oleifera leaves/sunflower seed cake. Meat Science. 2012;91(4):441-7.

30. Das N, Sikder K, Ghosh S, Fromenty B, Dey S. Moringa oleifera Lam. leaf extract prevents early liver injury and restores antioxidant status in mice fed with high-fat diet. 2012.

31. Kirisattayakul W, Wattanathorn J, Tong-Un T, Muchimapura S, Wannanon P, Jittiwat J. Cerebroprotective effect of Moringa oleifera against focal ischemic stroke induced by middle cerebral artery occlusion. Oxidative medicine and cellular longevity. 2013;2013.
32. Awodele $\mathrm{O}$, Oreagba IA, Odoma S, da Silva JAT, Osunkalu vo. Toxicological evaluation of the aqueous leaf extract of Moringa oleifera Lam.(Moringaceae). Journal of ethnopharmacology. 2012;139(2):330-6.

33. Stohs SJ, Hartman MJ. Review of the safety and efficacy of Moringa oleifera. Phytotherapy Research. 2015;29 